\title{
The Environmental Impact Assessment in the Polish Law - Selected Issues
}

\section{0cena oddziaływania przedsięwzięcia na środowisko w prawie polskim - wybrane zagadnienia}

\author{
http://dx.doi.org/10.12775/PYEL.2016.003
}

\begin{abstract}
The aim of article is to show basic aspects of the procedure of the environmental impact assessment during issuing environmental decisions in the Polish law with paying attention to some changes which will come into force on 1 January 2017.

* Law graduate; specialist in the Voivodeship Administrative Court; interested in: environmental law, family law and mediation.

** Ph.D. Candidate at the Chair of Environmental Protection Law, Faculty of Law and Administration, Nicolaus Copernicus University in Torun.
\end{abstract}




\section{Jakub Borowski, Martyna Walas}

The following parts of the article explain the concept of environmental impact assessment and the types of projects for which this procedure should be carried out mandatory and for which - optional. Carrying out the qualification of projects in the early stage by the authority plays an important role because it has an impact on the conduct of further administrative proceedings.

The further part of this article raises a fundamental stage of the environmental impact assessment which describes which duties of the applicant (investor) and which legal protective measures should be taken by the authority to ensure the proper implementation of the procedure. In particular, the article analyzes the matter of duty of submitting the environmental impact assessment report by the applicant, opinions and arrangements carried out by the administrative authorities, as well as ensuring possibility for public participation in the procedure.

\section{Keywords:}

Environment; environmental impact assessment.

\section{Streszczenie}

Niniejszy artykuł ma na celu przybliżenie procesu postępowania $\mathrm{w}$ sprawie oceny oddziaływania przedsięwzięcia na środowisko przy wydawaniu decyzji środowiskowych w prawie polskim. W kolejnych częściach artykułu wyjaśnione zostało pojęcie oceny oddziaływania przedsięwzięcia na środowisko oraz rodzaje przedsięwzięć, dla których to postępowanie należy przeprowadzić obligatoryjnie, a dla których fakultatywnie. Przeprowadzenie przez organ we wczesnym etapie postępowania kwalifikacji przedsięwzięć odgrywa istotną rolę, bowiem ma to wpływ na sposób prowadzenia dalszego postępowania administracyjnego.

W dalszej części artykułu poruszony został zasadniczy etap postępowania w sprawie oceny oddziaływania przedsięwzięcia na środowisko, który opisuje, jakie obowiązki spoczywają na wnioskodawcy (inwestorze) oraz jakie środki prawne zabezpieczające powinien podjąć organ, aby zapewnić właściwą realizację postępowania. W szczególności analizie poddana została kwestia obowiązku przedłożenia przez wnioskodawcę raportu o oddziaływaniu przedsięwzięcia na środowisko, opinie i uzgodnienia przeprowadzane przez organy administracyjne, czy też zapewnienie możliwości udziału społeczeństwa w postępowaniu.

\section{Słowa kluczowe:}

Środowisko; ocena oddziaływania na środowisko. 
The environmental impact assessment is a legal instrument that allows one to examine the impact of the project on certain elements of the natural environment. It can give a basis to indicate its possible impacts and intensity. This allows the administration authority, who grants in the form of an administrative decision consent to the implementation of the project, to assess the intensity of these interactions which justify identify measures to counter the influence of these interactions or which justify the lack of consent to the implementation of the project ${ }^{1}$. This institution was established as an instrument for carrying out preventive and comprehensive environmental policy ${ }^{2}$.

The beginning of the procedure of issuing environmental decisions, and thus performing the procedure of the environmental impact assessment, occurs principally at the request of the party who plans to take the project, directed to the competent authority. At this stage the authority performs assessment of the planned project on the basis of the submitted application. On the basis of the law, projects can be divided into two basic categories depending on the degree of their impact on the environment, that is:

a) projects which can always significantly affect the environment,

b) projects which can potentially significantly affect the environment.

The environmental protection system requires that the projects of the first category, according to article 59 of the Act of 3 October 2008 on Access to Information on Environment and its Protection, Public Participation in Environmental Protection and on Environmental Impact Assessment ${ }^{3}$, should be mandatorily the subject of impact assessment of the project on the environment, whereas in relation to projects which can potentially significantly affect the environment, the need for assessing the environmental impact assessment is stated by the authority who issues a decision on the basis of article 63 item 1 of the Act of 2008.

It should be noted that before the Act of 2008 entered into force, the procedure of the environmental impact assessment for the same project was carried out only once, in accordance with article 46 item 3 of the

\footnotetext{
1 R. Robaszewska, M. Płoszka, D. Kałuża, P. Wach, Decyzje środowiskowe, Warszawa 2015, p. 232.

2 See J. Jendrośka, Ocena oddziatywania na środowisko (OOŚ): Fachowa ekspertyza czy procedura z udziatem spoteczeństwa. Sytuacja w Polsce na tle tendencji światowych, Wrocław 1997, p. 56.

3 Journal of Laws of 2016 item 353, with further amendments; further referred to as: the Act of 2008.
} 
Act of 27 April 2001 - Environmental Protection Law ${ }^{4}$. At the moment the procedure can be carried out more than once 5 .

Extremely systemically important provision is article 72 of the Act of 2008, which contains a catalog of decisions which can be issued after obtaining environmental decision. This provision has been modified by the Act of 9 October 2015 on amendment to the Act on Access to Information on Environment and its Protection, Public Participation in Environmental Protection and on Environmental Impact Assessment ${ }^{6}$. In this modification it was provided inter alia that if the sole purpose of projects which can significantly affect the environment is the defense and security of the state or conducting rescue operations and to ensure civil security in connection with the prevention or removal of a direct threat to the population, the environmental decision is not issued if its issue would have a negative impact on those purposes. Implementation of such projects must, however, be notified to the regional director for environmental protection who may, within 7 days of the receipt of the notification, raise objection by the decision. If an objection is raised, there is the obligation to obtain an environmental decision.

Before any considerations to the issue of the obligation to conduct environmental procedure in the process of issuing environmental decision, it should be explained which entities are responsible for the conduction of such impact assessment. Both types of assessments are different when it comes to identifying entities responsible for carrying out the assessment. This matter is not expressly regulated by Community Law. It leaves it to the Member States free to determine the authorities responsible for conducting the assessment, both in the Directive 2011/92/EU of the European Parliament and of the Council of 13 December 2011 on the assessment of the effects of certain public and private projects on

4 Journal of Laws of 2016 item 672, with further amendments; further referred to as: the Environmental Protection Law.

5 K. Gruszecki, Ustawa o udostępnianiu informacji o środowisku i jego ochronie, udziale spoteczeństwa w ochronie środowiska oraz o ocenach oddziatywania na środowisko. Komentarz, Wrocław 2009, p.161.

6 Journal of Laws item 1936; further referred to as: the Act of 9 October 2015. 
the environment ${ }^{7}$, and in Council Directive 92/43/EEC of 21 May 1992 on the conservation of natural habitats and of wild fauna and flora ${ }^{8}$.

In the case of the impact assessment of projects which can significantly affect the environment there is a principle that both the decision on the need for conducting the assessment and the obligation to carry out the assessment itself, belongs to the authority who is competent to issue a permit for conducting the project.

For the impact assessment on the Natura 2000 the authority who is competent to issue a permit for conducting the project is intended only to initiate the whole procedure, but both the decision on the need for conducting the assessment and an obligation to carry out the assessment itself, belongs essentially to the authority for environmental protection (i.e. the regional director for environmental protection) ${ }^{9}$.

The issue of conducting the procedure of the environmental impact assessment for projects which can always significantly affect the environment does not create any major problems because the regulations contained in the Regulation of the Council of Ministers of 9 November 2010 on projects which can significantly affect the environment ${ }^{10}$, which reflects Annex I of the EIA Directive, include 53 categories of projects, classified on the basis of criteria of subject, or quantity, and therefore such which are characterized by type of production or quantity of production. In practice most problems can be raised by the qualification of specific projects to individual groups.

In terms of the problems indicated in the doctrine and practice the most difficult is the interpretation of new projects, so far unknown, such as renewable energy sources, installations for recycling or installations of mobile transmitting. The interpretation should take into account the objectives and functions of the whole regulations, in particular it should be possible to achieve the normative goals in the limits of the law.

7 OJ L 26, 28.01.2012, p. 1, with further amendments; further referred to as: the EIA directive.

8 OJ L 206, 22.07.1992, p. 7, with further amendments - Special edition in Polish: Chapter 15, Volume 2, p. 102.

9 M. Bar, J. Jendrośka, Ocena oddziatywania przedsięwzięcia na środowisko a ocena oddziatywania na obszar Natura 2000, in: Wybrane Problemy Prawa Ochrony Środowiska, eds B. Rakoczy, M. Pchałek, Warszawa 2010, p. 25-26.

10 Journal of Laws item 1397, with further amendments. 


\section{Jakub Borowski, Martyna Walas}

Transposition of the content of Annexes I and II of the EIA Directive in the Regulation mentioned above means support of the European legislator who is undoubtedly more experienced. It let to use the readymade and modern legal solutions. It should be emphasized that, according to the provisions of this Regulation, at present the list of projects is an open catalogue $^{11}$, despite the fact that the legislator used relatively casuistic terms and expressions. Despite using the experience of the European legislature and the national legislature, the situations where the qualification of the project is problematic cannot be avoided. In such case, the opposing positions of the investor and the authority will often wear down with each other. A small number of case law confirms, however, that such situations are exceptional, and the regulation is consistent, complete and adapted to the current level of development of science and technology $y^{12}$.

The obligation to conduct the environmental impact assessment can cause difficulties in the case of projects which can potentially significantly affect the environment. In this case, in accordance with article 59 item 1 point 2 of the Act of 2008, impact assessment is carried out optionally - by individual decision, undertaken in the form of the ruling, issued on the basis of the authorization indicated in article 63 item 1 of the Act of 2008 and the criteria of the individual selection mentioned in that provision.

It should be noted that the Act of 9 October 2015 has introduced, in the article 62a of the Act of 2008, a list of basic information about the planned project which must be included in the information sheet of the project. This information is intended to enable analysis of the conditions mentioned in article 63 item 1, or allow determining the scope of the report under article 69 item 1.

For the impact assessment on the Natura 2000 an obligation to conduct it is not related to the inclusion of the project on any list - it results from the existence of the possibility of "significant impact on the Natura 2000". That is why the requirement to this assessment relates to any project

11 K. Gruszecki, Prawnepodstawyoceny wptywu naśrodowisko oddziatywańskumulowanych, Samorząd Terytorialny 2012, No 3, p. 58.

12 M. Nowak, B. Dąbrowski, Ustawa o udostępnianiu informacji o środowisku i jego ochronie, udziale spoteczeństwa w ochronie środowiska oraz o ocenach oddziatywania na środowisko. Komentarz praktyczny, Warszawa 2013, s. 95 i 97; B. Opaliński, Ustawa o udostępnianiu informacji o środowisku i jego ochronie, udziale spoteczeństwa w ochronie środowiska oraz o ocenach oddziatywania na środowisko. Komentarz, Warszawa 2016, Legalis electronic version, Comment to article 60 . 
conducted anywhere, as long as there is a suspicion that it can significantly affect on Natura 2000 sites $^{13}$.

An individual decision of the authority for the obligation to conduct the impact assessment is called screening. Before taking the decision as to the need for lack of need for conducting the environmental impact assessment the authority that is competent to issue the environmental decisions must consult with the regional director for environmental protection. His/her opinion is mandatory, regardless of what is the position of the authority in this case. The lack of the consultation is a procedural defect resulting in the annulment of the decision.

In addition, when:

- the case concerned undertakings mentioned in article 72 item 1 point $1-3,10-13,15,16,18 a, 19$ and 22 of the Act of 2008 the opinion must be expressed by the authority of the health inspection who is competent,

- the project is conducted in the maritime area - the opinion must be expressed by the competent director of maritime office.

It should be noted that, in accordance with the Act of 9 October 2015, the catalogue of entities which are competent to issue an opinion will be expanded on the authority competent to issue an integrated permission which is based on the Environmental Protection Law, if the planned project is qualified as installation mentioned in article 201 item 1 of this act.

A significant modification which has been introduced by the Act of 9 October 2015 is also provision of article 64 item 1b, according to which if the regional director for environmental protection considers it necessary for the planned project to conduct the environmental impact assessment due to the effects on the Natura 2000, he/she should make arrangements by the ruling instead of issuing the opinion. It should be agreed with the view that this change is right ${ }^{14}$. The opinion is non-binding form of cooperation between the authorities and "making arrangements by the ruling" is eminently more decision-making.

In article 64 item 2 of the Act of 2008 it is exactly specified which applications and documents should be submitted by the authority who is competent in a case to issue an environmental decision to the authority who is competent to issue an opinion. Among those documents there

13 M. Bar, J. Jendrośka, Ocena..., p. 22.

14 B. Opaliński, Ustawa..., Comment to article 64. 
is for example the excerpt and the extract from the local development plan, if it was adopted for the site. The exclusions from this obligation concern the most important infrastructure projects in the country, and projects related to exploration and identification of minerals mentioned in item $2^{15}$.

It should be emphasized that these authorities have a period of 14 days to get acquainted with the application, the project information sheet and supporting documents, and to issue an opinion, by the ruling ${ }^{16}$, in the matter of the need for conducting the impact assessment.

The failure to issue an opinion by the authority of the health inspection who is competent to do this is considered as tacit acceptance (article 78 item 4), while in the case of the regional director for environmental protection that does not happen, and he/she is obliged to inform the parties of the delay. It is indicated that for the competent authorities of health inspection, the above term is a material term, and for the regional director for environmental protection - an instructive term ${ }^{17}$. After the transfer of the opinions by the competent authorities of to the authority who conducts the procedure and after public consultation, this authority has to issue an appropriate ruling. It should be emphasized that such ruling should be issued within 30 days from the date of the initiation of procedure (article 65 item 1).

During the assessment (screening) the authority who conducts the main procedure has obligation to provide opportunity for public participation in the procedure of the environmental impact assessment. It should be noted that this issue is not entirely clear. According to article 79 item 1 of the Act of 2008, the participation in these procedures is guaranteed for the society for which the environmental impact assessment is conducted. This means that in the procedures for which the assessment is optional, the participation of the society will be guaranteed from the moment of issuing the ruling which sets out the need for the impact assessment ${ }^{18}$.

It is generally assumed that the authority who conducts the main procedure is not bound by the opinion of the cooperating authority.

M. Nowak, B. Dąbrowski, Ustawa ..., p.104.

B. Opaliński, Ustawa..., Comment to article 64.

17 K. Gruszecki, Ustawa ..., p. 173; B. Opaliński, Ustawa..., Comment to article 64.

18 Judgment of Voivodeship Administrative Court in Kraków of 2 December 2013, II SA/Kr 1126/13. 
$\mathrm{He} / \mathrm{she}$ can take it into account or not. The authority is required to comprehensively assess the case and resolve the matter on his/her own indicating the reasons for that decision in the grounds of the ruling, which should include information about conditions of conducted selection. In case law, it is assumed that the opinion is not binding for the authority that decides on the need for the impact assessment on the environment of the planned project ${ }^{19}$. The ruling with its justification is delivered to the parties. The ruling concerning the determination of the obligation to conduct the impact assessment can be appealed by the party by the complaint ${ }^{20}$.

When the authority states the need for conducting a procedure for the environmental impact assessment, the appropriate environmental procedure begins. At this stage, determining the scope of the report is an important element. It should be noted that in the case of projects which can always significantly affect the environment, an investor submits an application for issuing the environmental decision with a report or he/she can submit additional application for request for determining the scope of the report. Such application is being consulted with the competent authorities who have 14 days for consideration. The legislator does not specify whether the authority who conducts the procedure is bound by the above opinion. Then, within 30 days the authority who conducts the procedure issues the ruling. The ruling defines the scope of the report. It cannot be appealed ${ }^{21}$.

As to the projects which can potentially significantly affect the environment the situation is different. For this type of projects submitting such applications seems pointless because at the initial stage it is not known whether there is a need for conducting the environmental procedure, and thus - whether there is the need for submitting the report. It seems that only in the case of issuing the decision about the need for the environmental impact assessment, the authority calls upon the applicant to submit the report.

19 See for example: Judgment of Voivodeship Administrative Court in Gorzów Wielkopolski of 2 June 2010, II SA/Go 232/10; Judgment of Voivodeship Administrative Court in Gdańsk of 12 January 2011, II SA/Gd 698/10; Judgment of Voivodeship Administrative Court in Lublin of 11 May 2011, II SA/Lu 866/10.

20 R. Robaszewska, M. Płoszka, D. Kałuża, P. Wach, Decyzje ..., p. 238.

21 Ibidem, p. 241-242. 


\section{Jakub Borowski, Martyna Walas}

It should be emphasized that the rulings of the authorities who cooperate in the procedure of deciding on the need for the environmental impact assessment of the project, as only expressing an opinion, which is the weakest form of cooperation between administrative authorities, are not binding for the authority who is competent to decide on the need for environmental impact assessment. Because of that this authority will definitively decide on the need for the environmental impact assessment of projects for which it is optional. Therefore, the assessment made in this field should be comprehensive. In no case it can be limited to opinions made by the cooperating authorities ${ }^{22}$. Similarly, the Voivodeship Administrative Court in Lublin in its judgment of 20 January $2011^{23}$ stated that the opinion mentioned in article 64 item 1 is not binding for the authority on the need for the environmental impact assessment of the proposed project.

The legislature, in article 63, included conditions which should be taken into account during the environmental impact assessment of the planned projects which can potentially significantly affect the environment. It should be noted that the Act of 9 October 2015 introduced a number of changes to that provision, which are primarily caused by the necessity of adjusting the Polish law to the requirements of the EIA directive. They are both of essential and procedural character. One of the major changes is determining the final date for submitting the report. In case of failure to submit the report within 3 years from the date of suspension of the procedure mentioned in item 5 , the request to initiate the procedure of issuing the environmental decision shall be considered to be withdrawn.

After issuing the ruling which declares the need for the environmental impact assessment, the procedure is suspended until the time of submitting the full report by the investor.

It should be explained that the suspension of the procedure should take place only after stating that the ruling on the obligation to conduct the environmental impact assessment becomes final, so only in the case that it was not appealed by the complaint. The suspension does not concern only the procedure at first instance, but the entire administrative procedure, that is why too early suspension could block the consideration of a complaint against the ruling on the environmental impact assessment ${ }^{24}$. It should

\footnotetext{
K. Gruszecki, Prawne podstawy..., p. 60.

23 II SA/Lu 698/10.

24 R. Robaszewska, M. Płoszka, D. Kałuża, P. Wach, Decyzje..., p. 302.
} 
be also stressed that the ruling which suspends the procedure of issuing the environmental decision cannot be appealed by any instrument.

When the applicant submits the report, the procedure of the environmental impact assessment enters its crucial stage.

The report is a specific, unique document which concerns the analysis of potential impacts, risks and ways of repairing the damage caused in the environment by the proposed project. The specific nature stems from the comprehensive impact assessment which is contained in it and from the analysis of the technological aspects in conjunction with each other ${ }^{25}$.

The report is an important, if not the most important, document in the procedure of the environmental impact assessment. Its task is to determine what will be the scope of the impact of the proposed project on the environment, with taking into account the planned investment solutions and with a summary of other possibilities (variants) ${ }^{26}$. It should facilitate the determination of "all potential risks related to the conduction of the planned project" ${ }^{\prime 2}$.

It is worth mentioning the judgment of the Supreme Administrative Court of 18 March $2009^{28}$ and of the Voivodeship Administrative Court in Lublin of 18 March $2011^{29}$. In its justifications it was indicated that the report is a document of a private investor as a proof of in the environmental procedure so de facto in the administrative procedure.

The Polish legislator does not point out who should prepare the report. According to the current law, the report may be prepared by any natural person or legal entity because the law does not require the author to demonstrate a professional theoretical or practical knowledge ${ }^{30}$. In some sense the qualifications of the entity which prepares the report arise,

25 Comprehensively about the legal nature of the report: J. Szuma, Charakter prawny raportu o oddziatywaniu przedsięwzięcia na środowisko, in: Zasada zrównoważonego rozwoju w wymiarze gospodarczym i ekonomicznym, eds B. Rakoczy, K. Karpus, M. Szalewska, M. Walas, Toruń 2015, p. 279-295.

26 Ibidem, p. 303-304.

27 P. Korzeniowski, Instytucje prawne ochrony środowiska a proces inwestycyjno-budowlany. Studium Prawno-administracyjne, Warszawa 2012, p. 85.

28 II OSK 383/08.

29 II SA/Lu 845/10.

30 A. Kosieradzka-Federczyk, "Raport o oddziatywaniu przedsięwzięcia na środowisko” w orzecznictwie sądów administracyjnych, Zeszyty Naukowe Sądownictwa Administracyjnego 2012, No. 1, p. 48. 
however, from the type of the projects and the scope of the report because the data and analysis that should be found in it require a high level of knowledge and experience of the authors. Undoubtedly, the investor who orders the preparation of the report should be interested in choice of the authors with the appropriate preparation and qualifications for such work. The authors should provide an objective and devoid of influence attitude to the subject ${ }^{31}$.

However, it was postulated in the doctrine that the team of authors should include people with professional education, i.e. an urban planner, architect or landscape architect because the environmental impact of the project must be defined precisely and correctly and in accordance with essential aspects ${ }^{32}$. It should be noted that, according to the Act of 9 October 2015, the authors of the report, since 1 January 2017, like as the authors of the forecasts, will have to meet the requirements mentioned in article $74 \mathrm{a}$ item 2 of the Act of 2008. Under this provision the author of the report should be a person who graduated at least first-cycle or second-cycle studies, or long-cycle studies in the fields related to the education in the area of: science in the fields of chemical sciences, natural sciences in the fields of biological sciences and earth sciences, technical sciences in the fields of technical sciences disciplines: biotechnology, mining and engineering geology, environmental engineering or the sciences of agriculture, forestry and veterinary fields of agricultural sciences, forestry sciences, or graduated at least first-cycle or second-cycle studies, or long-cycle studies and have at least 5 years of experience in the work in the teams preparing reports or environmental impact forecasts, or participated in the preparation of at least 5 such reports or forecasts.

The report should be submitted usually in three copies $^{33}$ together with its record in the electronic form on the computer data carriers. Article 66 item 1 of the Act of 2008 contains a detailed directory that specifies what elements should be included in the report. Those elements are often

31 R. Robaszewska, M. Płoszka, D. Kałuża, P. Wach, Decyzje ..., p. 303-304.

32 M. J. Nowak, Z. Tokarzewska-Żarna, Ustawa krajobrazowa, rewitalizacyjna $i$ metropolitalna. Komentarz do przepisów o planowaniu i zagospodarowaniu przestrzennym, Warszawa 2016, Legalis electronic version, Comment to article 66 of Act on Access to Information on Environment and its Protection, Public Participation in Environmental Protection and on Environmental Impact Assessment.

33 If the director of maritime office takes part in the procedure, 4 copies of report should be submitted (article 74 item 2). 
subject to some modifications, made in the opinion issued by the authority, and are adapted to the needs of the planned project. It should be noted that since 1 January 2017 a number of changes to the content of the report will come into force. They were introduced by the Act of 9 October 2015 because of the need to implement the provisions contained in the European Union law.

An important element of the report is preparing variants which involve identifying three variants (possible solutions) of the planned project with the description. They should be identified by the investor. The legislator indicates the variant proposed by the applicant, the rational alternative variant and also the variant that is the most favorable for the environment (article 66 item 1 point 5).

The report must specify the expected environmental impact of the analyzed variants including also the event of a major industrial accident. The report should include the justification of the variant offered by the applicant together with its impact on the environment (article 66 item 1 points 6 and 7 ).

It should be explained that the most favorable variant is the model variant. It corresponds ideally with the environmental protection. The alternative variant should be a solution that is possible to carry out from the economic and technical point of view. It should be different than the one which the investor prefers but it should fulfill his goals at the same time.

Preparing variants of the project is very important in the environmental impact assessment of the project. To provide the authority with the possibility of full impact assessment of the project, the Act of 2008 provided the possibility of comparison and even the possibility of making the choice other than proposed by the investor. All variants must be treated with due attention and widely described. No description or laconic description may even disqualify the report ${ }^{34}$.

It should be emphasized that the authority is obliged to examine all proposed variants and evaluate them on their own without relying on the justification of the report or being suggested by it. Therefore, the authority has the possibility, but also the duty, to choose the most appropriate variant from the perspective of the impact of projects on the environment, according to the principle of sustainable development ${ }^{35}$.

34 R. Robaszewska, M. Płoszka, D. Kałuża, P. Wach, Decyzje ..., p. 317-318.

35 B. Opaliński, Ustawa..., Comment to article 81. 
On the grounds of the justification to the judgment of the Supreme Administrative Court of 6 February $2013^{36}$, it can be concluded that the authority should decide whether the report is coherent, logical and complete in terms of form and content. If the assessment of the report is positive, the authority may waive the detailed verification. If, however, the authority decides that he/she requires special knowledge, the authority can ask the expert or experts for an opinion. In a case when the authority comes to conclusions different than those proposed in the report, there is the possibility of "arrangement" between the interests of the authorities and the applicant. It is possible by the implementation of a different variant than originally indicated. Due to such solution the need to conduct the whole procedure again can be avoided. Of course when the investor refuses to agree to another variant, the authority is forced to refuse consent for the conduction of the project, which means issuing a negative decision. The consequence of this is the need for full verification of the report by the authority who conducts the procedure ${ }^{37}$.

It should be explained that the application of the provisions allowing for a refusal to issue the environmental decision because of the lack of consent of the investor on the variant which was indicated by the authority causes procedural difficulties. The first one is implied by article 81 of the Act of 2008 which uses the prerequisite for the legitimacy of conducting the project in the variant different form the one proposed by the applicant. This prerequisite indicates that there is an opportunity to extend beyond the variants contained in the report, under the influence of the findings of the environmental impact assessment. The result is that the authority will often not have the details of such variants or detail appropriate for the possibility for their comparison with the variants contained in the report. This authority was not also provided by the legislature with the possibility to ask the investor to supplement the report or provide any other evidence to disable additional variants selected for comparative analysis. Consequently, the burden of proving the validity of the new preference variant as a basis for decision lies with the authority.

The variant other than the one proposed, chosen in the procedure of public participation, or as a result of the opinion of the authority who cooperates, means that one of the procedures must be repeated in order to

II OSK 1862/11.

37 R. Robaszewska, M. Płoszka, D. Kałuża, P. Wach, Decyzje ..., p. 326-327. 
protect the whole process from the allegation that public participation was ostensible or that there was a manipulation in this procedure. If this has to be a "co-decision" of binding character, the basis for arrangements should be also supplemented ${ }^{38}$.

The case law refers to several problems associated with preparing variants of the project. The Voivodeship Administrative Court in Gdańsk pointed out, for example, in its judgment of 24 March 2011 that it is not sufficient to present only the variant of the applicant in the report and the variant consisting in the fact that the project would not be taken because it is not a rational alternative variant ${ }^{39}$.

On the other hand, if the investor does not propose to choose the variant which is the most beneficial for the environment, he/she is obliged to present in the report the reasons for conducting the preferred variant, including for example economic analysis of the conduction of the project in other variants, the identification of social costs (eg. the demolition of buildings, etc.), calculation of the profitability of the project in the selected variant, so the circumstances confirming the validity of the selection. These issues in this case are subject to the merits of the assessment of the authority competent to issue the environmental decision, as important for the way of consideration of the case ${ }^{40}$.

There should be said something about public participation in conducting the environmental impact assessment. Under the Act of 2008, before the environmental decision is issued, the authority competent to issue it, provides the opportunity for public participation in the procedure under which the environmental impact assessment is conducted (article 79).

It should be explained who should be understood by the term "society". The personal scope of the term includes any natural person acting individually and people acting in organizations for which the protection of the environment is the subject of their activity. Then they have the status of an environmental organization. They may have a legal status as entities acting under the provisions of the Act of 7 April 1989 - Law on Associations ${ }^{41}$.

\footnotetext{
38 M. Behnke, Analiza wariantowania jako przestanka wskazania wariantu innego niż proponowany przez inwestora lub odmowy wydania decyzji środowiskowej, in: Wybrane Problemy Prawa Ochrony Środowiska, eds B. Rakoczy, M. Pchałek, Warszawa 2010, p. 70-71.

39 II SA/Gd 864/10.

40 Judgment of Voivodeship Administrative Court in Warsaw of 8 November 2010, IV SA/Wa 929/10.

41 Journal of Laws of 2015 item 1393, with further amendments.
} 
According to the EIA Directive, public participation should take place at the latest when it can reasonably be expected to submit such information. It should be assumed that in the case of projects from the Group I (the report was submitted together with the application) public participation begins in parallel to the initiation of the procedure. In case of other projects the procedure with public participation occurs when an investor submits the report and the suspended procedure is taken ${ }^{42}$.

Public participation starts with the public disclosure of information relating to the proposed project. The authority who provides public information about the initiation of procedure has the obligation to include all necessary information in it. The most frequent errors at this stage are the lack of information about opportunities to familiarize oneself with necessary documentation, no information about the place where information is available and faulty indication of the term of 7 days rather than 21 days to submit conclusions and observations. Those facts are confirmed in the judgment of the Voivodeship Administrative Court in Poznań of 16 April $2014^{43}$.

At the end of the procedure of the environmental impact assessment the authority, before issuing the environmental decision in accordance with article 77 of the Act of 2008, makes an agreement on the conduction of the project with the competent authorities of public administration. These activities are carried out after collecting all evidence in the case. The agreement procedure has a special character because, according to article 77 item 7 of the Act of 2008, the provisions of article 106 item 3, 5 and 6 of the Act of 14 June 2012 - the Code of Administrative Proceeding ${ }^{44}$ do not apply. The scope of exemption is, however, limited, because it concerns the deadlines for resolving the case, the admissibility of the appeal against the decision on the opinion, the arrangements, as well as complaints about the inactivity of the authority ${ }^{45}$. Generally, it is assumed that the ruling on the agreement should be issued within 30 days of receipt of the required documents. It should be remembered that this term has instructional value. The authority who proceeds with the case, when applies for the agreement, submits the investor's application for issuing the environmental decision,

42 R. Robaszewska, M. Płoszka, D. Kałuża, P. Wach, Decyzje ..., p. 339-340.

43 II SA/Po 1157/13.

44 Journal of Laws of 2016 item 23, with further amendments.

45 B. Opaliński, Ustawa..., Comment to article 77. 
the report and the excerpt and the extract from the local development plan if it was adopted or information about the lack of it. The agreements mean that the authority refers to the proposed conclusion. That is why it is necessary to present the agreeing authority the draft of the decision. It may happen that in one procedure the authority will apply for the agreement to the conduction of the project because the agreeing authorities, after finding deficiencies or weaknesses, will call for their removal repeatedly.

In the case when the cooperating authority does not see significant weaknesses, it issues the ruling in which they agree with the conduction of the project and lays down its conditions. It should be emphasized that although the agreement procedure is ancillary and is a part of a broadly defined procedure in the main case, its result is binding for the authority who conducts the main procedure, and cannot be verified by this authority ${ }^{46}$.

The article shows how much work belongs to the authorities of the public administration in connection with the initiation of environmental procedure. One of the most important duties of the authority arising from the initiation of the procedure is to call the applicant (investor) to submit a report. This institution raises a number of concerns, both in the doctrine and in the jurisprudence. The basic problem connected with it is to determine who should make a report, what is its legal nature, or how to determine the scope of the report and its variants. The proper conduction of the environmental procedure largely depends also on fulfilling other obligations which arise from the provisions of the Act of 2008, and which belong to the authority who issues the environmental, for example insightful conduction of the screening and the obligation to ensure public participation during the conduction of the environmental impact assessment. In conclusion, it should be noted that all authorities involved in the environmental procedure should work together efficiently to ensure the implementation of the principles of thoroughness and speed of administrative proceedings.

It should be noted that the environmental procedure is a procedural institution ${ }^{47}$. For this reason the procedure is very detailed. It has to serve the search for the best solution, the least detrimental to the environment. The searching should be done on the basis of a comprehensive examination

46 R. Robaszewska, M. Płoszka, D. Kałuża, P. Wach, Decyzje ..., p. 328-335.

47 W. Radecki, Ocena oddziatywania na środowisko, in: Instytucje prawa ochrony środowiska. Geneza-rozwój-perspektywy, ed. W. Radecki, Warszawa 2010, p. 301. 


\section{Jakub Borowski, Martyna Walas}

of the possible impacts on the environment and consider the different possible variants ${ }^{48}$.

It should be emphasized that the Act of 9 October 2015 has introduced a number of changes which, because of their sheer size, are not mentioned in this article. It should be noted that the objective of this act was to implement the EIA Directive amended by Directive 2014/52/EU of the European Parliament and of the Council of 16 April 2014 amending Directive 2011/92/EU on the assessment of the effects of certain public and private projects on the environment ${ }^{49}$. The Act assumed adjusting the Polish law to Directive 2003/4/EC of the European Parliament and of the Council of 28 January 2003 on public access to environmental information and repealing Council Directive 90/313/EEC ${ }^{50}$ due to the incorrect transposition of Directive 2003/4/ EC in the Act 2008. Moreover, the aim of the Act was to make significant changes to streamline the investment process.

\section{Bibliography}

Bar M., Jendrośka J., Ocena oddziatywania przedsięwzięcia na środowisko a ocena oddziatywania na obszar Natura 2000, in: Wybrane Problemy Prawa Ochrony Środowiska, eds B. Rakoczy, M. Pchałek, Warszawa 2010.

Behnke M., Analiza wariantowania jako przestanka wskazania wariantu innego niż proponowany przez inwestora lub odmowy wydania decyzji środowiskowej, in: Wybrane Problemy Prawa Ochrony Środowiska, eds B. Rakoczy, M. Pchałek, Warszawa 2010.

Gruszecki K., Prawne podstawy oceny wptywu na srodowisko oddziatywań skumulowanych, Samorząd Terytorialny 2012, No 3.

Gruszecki K., Ustawa o udostępnianiu informacji o środowisku i jego ochronie, udziale spoteczeństwa w ochronie środowiska oraz o ocenach oddziatywania na środowisko. Komentarz, Wrocław 2009.

Jendrośka J., Ocena oddziatywania na środowisko (OOŚ): Fachowa ekspertyza czy procedura z udziatem spoteczeństwa. Sytuacja w Polsce na tle tendencji światowych, Wrocław 1997.

48 Ibidem.

49 OJ L 124, 25.04.2014, p. 1, with further amendments.

50 OJ L 41, 14.02.2003, p. 26, with further amendments - Special edition in Polish: Chapter 15, Volume 7, p. 375. 
Korzeniowski P., Instytucje prawne ochrony środowiska a proces inwestycyjnobudowlany. Studium Prawno-administracyjne, Warszawa 2012.

Kosieradzka-Federczyk A., „Raport o oddziatywaniu przedsięwzięcia na środowisko” w orzecznictwie sądów administracyjnych, Zeszyty Naukowe Sądownictwa Administracyjnego 2012, No 141.

Nowak M., Dąbrowski B., Ustawa o udostępnianiu informacji o środowisku i jego ochronie, udziale spoteczeństwa w ochronie środowiska oraz o ocenach oddziaty wania na środowisko. Komentarz praktyczny, Warszawa 2013.

Nowak M. J., Tokarzewska-Żarna Z., Ustawa krajobrazowa, rewitalizacyjna $i$ metropolitalna. Komentarz do przepisów o planowaniu i zagospodarowaniu przestrzennym, Warszawa 2016.

Opaliński B., Ustawa o udostępnianiu informacji o środowisku i jego ochronie, udziale spoteczeństwa w ochronie środowiska oraz o ocenach oddziatywania na środowisko. Komentarz, Warszawa 2016.

Radecki W., Ocena oddziatywania na środowisko, in: Instytucje prawa ochrony środowiska. Geneza - rozwój-perspektywy, ed. W. Radecki, Warszawa 2010.

Robaszewska R., Płoszka M., Kałuża D., Wach P., Decyzje środowiskowe, Warszawa 2015.

Szuma J., Charakter prawny raportu o oddziatywaniu przedsięwzięcia na środowisko, in: Zasada zrównoważonego rozwoju w wymiarze gospodarczym i ekonomicznym, eds B. Rakoczy, K. Karpus, M. Szalewska, M. Walas, Toruń 2015.

\section{Emails:}

jakub.borowski86@gmail.com

martyna.walas@gmail.com 